Article

\title{
Genocide Discourses: American and Russian Strategic Narratives of Conflict in Iraq and Ukraine
}

\author{
Douglas Irvin-Erickson \\ The School for Conflict Analysis and Resolution, George Mason University, Arlington, VA 22201, USA; \\ E-Mail: dirviner@gmu.edu
}

Submitted: 2 May 2017 | Accepted: 14 August 2017 | Published: 29 September 2017

\begin{abstract}
This paper presents the concept of "genocide discourses", defined as a type of strategic narrative that shapes the way individuals and groups position themselves and others and act, playing a critical role in the production of violence and efforts to reduce it. Genocide discourses tend to present genocide as fundamentally a-political, and hold that genocidal systems are dislodged only when they are swept away through external violence. Secondly, genocide discourses are built on an assumption that the victims of genocide are necessarily moral innocents, not parties in conflict. These two factors make genocide discourses highly effective in conferring moral capital upon certain actors in a conflict. The two principles converge to produce strategic narratives that direct political and military actions in certain ways in the context of contentious conflicts and political violence, motivating humanitarian responses in defense of certain groups, or sustaining popular support for foreign wars. The paper illustrates the argument by examining two case studies between 2014 and 2017: the debates in the United States over Islamic State genocides, and the conflict between Ukraine and Russia.
\end{abstract}

\section{Keywords}

genocide; Iraq; Islamic State; Russia; strategic narratives; Ukraine

Issue

This article is part of the issue "Narratives of Global Order", edited by Matthew Levinger (George Washington University, USA) and Laura Roselle (Elon University, USA).

(C) 2017 by the author; licensee Cogitatio (Lisbon, Portugal). This article is licensed under a Creative Commons Attribution 4.0 International License (CC BY).

\section{Introduction}

When the Russian Federation invaded Ukraine in 2014 and annexed Crimea, accusations of genocide were unleashed on all sides of the conflict. Ukrainian nationalists accused the Soviet Union of committing genocide against Ukraine in the 1930 s and 1940s. The Russian government, in turn, denied the Soviets committed genocide and accused the Ukrainian government of attempting to manufacture past Soviet genocides to cover up the fact that Ukrainian nationalists currently were plotting genocide against ethnic Russians. Depending on one's position in the conflict, therefore, the Russian invasion of Ukraine is either seen as an effort to save ethnic Russians from genocide in eastern Ukrainian, or an illegal military invasion undertaken by a Russian government in Moscow that claims historical dominance over Ukraine because of a political arrangement that was achieved by Stalin through genocide in the 1930s and 1940s.

In another conflict, seemingly a world away, we find a similar genocide discourse at work. In 2014, the United States government began to indicate that it was inclined to determine the Islamic State of Iraq and the Levant (ISIL) was committing genocide (Kerry, 2014). When it became apparent that United States officials would seek to declare ISIL's treatment of the Yezidi religious minority to be genocide, Christian groups in the United States mobilized to pressure congressional representatives to pressure the State Department to include Christians as victims of ISIL genocide (Toosi, 2015, 2016). The goals of this movement, which was in many ways led by the Catholic organization the Knights of Columbus, were humanitarian and grounded in an authentic impulse to provide relief to those who were suffering, even if this humanitar- 
ian response was rooted in their own politics. The response employed a genocide discourse to build sympathy amongst Christian lobby groups in the United States to pressure the government to expand the number of Syrian and Iraqi refugees (of all religious groups) accepted by the United States. But this genocide discourse, which used the suffering of Christians as a bridge for mobilizing American sympathy to all the victims of ISIL, was quickly eclipsed by a second, parallel genocide discourse that presented Islam, and especially Sunni Islam, as a genocidal evil that had to be eradicated. This second genocide discourse undercut the goals of the first, as humanitarian sympathy for the victims of ISIL gave way to movements calling upon Americans to care for the victims of ISIL by eradicating ISIL, which delegitimized the incipient attempts by Catholic social justice lobby groups to increase the number of refugees accepted by the United States.

I define "genocide discourse" as a type of strategic narrative, where a strategic narrative is understood in part as a "compelling story [line] which can explain events convincingly and from which inferences can be drawn" (Freedman, 2006, p. 22). Strategic narrativeswhether they are articulated at an interpersonal, intergroup, national, or inter-national level-shape the way individuals and groups position themselves and others, and act (Cobb, 2013, pp. 4-5; Smith, 2003). The inferences that strategic narratives engender play a crucial role in legitimizing or motivating certain kinds of actions, creating a set of assumptions about a given conflict that can prescribe, or even motivate, certain responses or actions. For instance, to state that a group in a conflict is a victim of genocide confers upon that group a kind of innocence, helplessness, or defenselessness. This, in turn, can elicit sympathy to their position, and prescribe certain actions be undertaken, presumably, in their defense. Because such actions are inferred, not stated explicitly, strategic narratives in times of armed conflict can be efficient movers of public opinion, legitimizing the conflict and stifling public debate and critical inquiry, while fostering a commonly held perception that the conflict is not a policy choice of elites and leaders but rather something unavoidable, even natural. They can also set in motion reductionist explanations of conflict that elide meaningful distinctions between actors in conflict. This is precisely what genocide discourses are intended to do-to collapse the social, political, economic, cultural, religious, and historical contexts of any conflict into a simple binary of good guys and bad guys. By explaining conflicts in binary terms, genocide narratives can bolster exclusionist rhetoric, crystalizing positions in a conflict, or responses to a conflict, in unequivocal terms (Feierstein, 2013).

Strategic narratives can be transnational, adopted and adapted by groups, in reference to local responses to local politics or global politics. As such, they can be "global narratives" that "criss-cross the world" and "play a critical role in the production of violence, as well as in the international policies and practices that seek to contain or reduce it" (Cobb, 2013, p. 4). This was the case, for example, in a global interplay that occurred as local Catholic groups around the world began to advocate for humanitarian policy responses in defense of the victims of ISIL genocides in North Africa and the Middle East. These Catholic lobbying efforts motivated a movement in Lithuania, which prompted a resolution in the Seimas of the Republic of Lithuania recognizing "The Genocide of Christians and Other Religious Minorities in the Middle East And North", (Seimas of the Republic of Lithuania, 2015), which was cited by the Knights of Columbus in their 200-page documentation of genocides committed by ISIL against religious minorities that they submitted to the United States House of Representatives, calling on the United States Congress to recognize genocides committed by ISIL against all religious minorities-including Muslim groups.

The genocide discourses examined in this article are types of strategic narratives in which the deployment of the concept of genocide, either purposefully or reflexively by parties to the conflict, or by third parties or outside actors, provides an organizing framework for collective action, defining a community's identity, its values and goals, and the stakes of its struggles, vis-à-vis an other in a conflict. The application of the concept of genocide within a strategic narrative carries a set of assumptions about what genocide is, what kinds of people commit genocide, and what kinds of people experience genocide. And, importantly, it carries assumptions about how these people who commit or experience genocide should be treated, and how individuals and groups should respond to genocide. In some instances, therefore, a genocide discourse can play a generative role in a conflict, shaping decisions undertaken by groups and states beyond other forces such as immediate economic interests. More frequently, a genocide discourse is coopted or directly employed as a framing device by elites and leaders, such as national policy makers, within the context of a larger strategic narrative, to try and shape group support and promote group cohesion around a particular goal. Scholars have demonstrated that actors in conflicts around the world have attempted-sometimes successfully-to portray themselves as victims of genocide in order to convince powerful foreign states to interfere in a conflict on their behalf (Kuperman, 2008). This paper advances a similar argument, attempting to shed light on the way certain actors determine that some groups are victims or perpetrators of genocide and other are not, in order to alter the way those actors are perceived and treated, and thereby advance their own strategic goals within the context of larger conflicts.

\section{Genocide Discourses}

\subsection{Victims, Politics, and Legacies of Totalitarianism}

There are two historic, organizing principles of the genocide prevention movement. The first is that external vi- 
olence is the only means of stopping genocide. The cutting edges of the atrocity prevention field of practice focus on improving the ability of people in influential positions to identify genocidal processes and make ethical decisions to resist genocide (Waller, 2016), while bolstering peace processes that provide a context in which these decisions can be made and supported (Moix, 2016; Rosenberg, Galis, \& Zucker, 2016). Such approaches, prominent amongst peacemaking practitioners, reject the assumption that genocide can only be prevented through external force or armed force. What is notable in these cases, however, is that scholars and practitioners who advocate for such an approach simply avoid using the word genocide all together (see Weiss, 2012), or they go to great lengths to argue that genocide is not an act, but a complex social process in which individuals are constantly making decisions that allow genocide to occur (see Waller, 2016). In fact, when activists and policy makers deploy the language of "mass atrocity prevention" or "the responsibility to protect" instead of using genocide, and when they differentiate between crimes against humanity and genocide, they acknowledge a wide range of non-violent and non-coercive ways of preventing or stopping atrocities (Irvin-Erickson, 2017a; Weiss, 2012). When the word genocide emerges in academic and social discourses about a given conflict, however, a different set of assumptions is put in place, assumptions that tend to privilege external violence as the only path towards peace. What is it about the word genocide that makes people see a conflict differently when the word genocide is used instead of another term? What is it about the word genocide, and the word's connotations, that lead people to see violence as the only way to prevent the act?

This pillar of the genocide prevention tradition has its roots in a closely related field of study, the study of totalitarianism. Raphaël Lemkin, in Axis Rule in Occupied Europe, the book in which the word genocide first appears in print, framed his study of Axis governments as a study of totalitarianism (Lemkin, 1944, p. ix). The theory of totalitarianism in the 1920 s and early 1930 s centered around a belief that the total state altered the social fabric of society to eliminate the basis of political opposition, or to create a "new man" in order to facilitate the ideological goals of a regime. Lemkin, on the other hand, would disaggregate the concept of totalitarianism - the "total" control of a political regime over political and social life-from the practice of altering the social fabric of society through violence and coercion, a practice he called genocide. In Lemkin's foray into this theory, he used the term genocide to refer to the destruction of social groups. This allowed him to argue that genocide was as old as human history, but became a useful strategy of governing that was employed by totalitarian governments. Genocide, for Lemkin, was therefore not intrinsic to totalitarianism. However, Lemkin's views on genocide and totalitarianism were never widely accepted (Irvin-Erickson, 2017b). A host of other theorists brought genocide studies to a position that resembled the study of totalitarianism, and set the pace for genocide prevention movements of the second half of the twentieth century.

Hannah Arendt (1951) believed totalitarian regimes used violence and terror to obliterate political life. Borrowing from the zeitgeist of the day (lakovou, 2009; Söllner, 2004), her central notion was that totalitarian regimes ruled through violence and terror. Totalitarian regimes, for Arendt, could not be swept away by political movements within their societies. Instead, brutal yet irrational, they could only come to an end when their irrational priorities led to internal collapse, or when they were toppled externally through violence. A similar belief can be found in the writings of Karl Wittfogel (1931, $1938,1957)$ who is known in English language scholarship for Oriental Despotism: A Comparative Study of Total Power, which synthesized much of his previous scholarship on the total systems of power in oriental and Chinese states. In his study of "hydraulic dynasties" that ruled by monopolizing access to water in their empires, Wittfogel argued that the administrative infrastructure needed to control access to water and irrigation generated governmental institutions that were well-suited for serving as mechanisms of social control-such as specialized bureaucracies and military units designed not for fighting wars but enforcing laws. These institutions generated and maintained social hierarchies, and buttressed the power of ruling elites. While there were pretenders to the throne who were constantly warring and assassinating each other, the dynasties as a whole survived despite the internal divisions, Wittfogel argued, because each dynasty's political power was derived from its total control over the social and political institutions of the society. Totalitarianism, for Wittfogel, was functional, not irrational, leading him to argue (against Arendt) that such regimes would not self-destruct. Since these institutions gave the rulers of these states the ability to obliterate the social and political groups that opposed them, the only way the dynasties fell, Wittfogel argued, was when they were swept away by military forces from outside of their own social and political base.

The basic thesis was nearly ubiquitous throughout the anti-totalitarianism and genocide prevention movements and traditions. The jurist Antoni Wereszczyński (1928), a major figure in Lemkin's intellectual circles whom Lemkin drew upon, argued that the totalitarian regimes of Europe did not arise from military coups, but from revolutionary upheavals with a social basis. Once in power, the revolutionary organization "relies on the apotheosis of the state, on a belief in its almost miraculous might, on a strict connection between the state and the victorious organization or its leader, and on the elimination of the rest of the population from having any influence at all" (as cited in Kornat, 2006, p. 84). Any political machinations of the population to try and put an end to the regime and its systems of violence were therefore futile-violence was the only way out, because 
the state itself was willing to kill entire groups who had alternate ideas about how the society should be governed. In another classic study of totalitarianism, Franz Neumann (1942) argued that the National Socialist Party in Germany constructed a "state-less" state that lacked modern political institutions necessary for reining in the power struggles of competing groups whose only common ground was hatred, propelling the state towards uncontrolled violence and expansionary war. Sigmund Neumann (1942), on the other hand, proposed that the totalitarian state was brought into being through a oneparty system that mobilized masses of people in support of its program by stoking anger at imagined enemies, and then violently crushing internal political opponents through a military apparatus created to fight these imagined external foes. Thus the totalitarian government, for Sigmund Neumann, created a state of permanent revolution through which it stayed in power, exclusively, by generating imaginary enemies of the revolution. Both Franz and Sigmund Neumann, coming from different starting points, arrive at the belief that the totalitarian state's murderous willingness to annihilate entire groups was the pillar of its strength, and would only come to an end through the internal collapse of the state and the regime (when they ran out of imagined enemies and began to kill their own supporters), or through external force. And, finally, Ernst Fraenkel (1941/2017), argued that the National Socialist government divided German law into two competing areas, forming a "prerogative state" governed by the party which ruled through arbitrary violence, and a "normative state" which maintained the legal order and protected the legitimacy of German courts. Here, again, we find a situation close to Wereszczyński's terms, where the legal system of totalitarian regimes eliminates individual rights and asserts state control over the life and property of the ruled, allowing political enemies to be repressed violently but legally, while legalizing and empowering an "unthinking grey mass, a mob whipped along in the direction indicated by the almighty rulers" (as cited in Kornat, 2006, p. 84). From Wereszczyński, Wittfogle, Neumann, Neumann, Fraenkel, and Arendt, among others, thus was born an intellectual tradition that has animated the genocide prevention and humanitarian intervention movements for the last century: the idea that once a regime becomes genocidal or totalitarian, internal collapse or violent intervention from the outside are the only ways the regime, and the mass violence it commits, can be brought to an end. As Arendt put it in On Violence, in the totalitarian state that rules through violence, the only pillars of political power for the regime are the state security forces and a network of informers-beyond this, political or moral challenges to the regime and its violence are utterly useless (Arendt, 1970, pp. 81-84).

After this generation of thinkers, totalitarianism quickly became an "essentialist" concept, employed in social scientific and political discourse to justify American democracy over Soviet communism and fascism
(Spiro \& Barber, 1970). Dirk Moses (2006) has observed that the field of genocide studies resembles "a version of totalitarianism theory" because "the definition of genocide-at least a true one [according to the field's theorists]-can only be committed by a totalitarian or at least authoritarian state driven by a utopian ideology". This is why, Moses writes, when the word genocide is invoked, public, policy, and scholarly debates in the United States tend to focus on the ideological or religious-political dynamics of a regime. For example, the debates in the United States over the Darfur genocide in the late 2000s became "preoccupied with the Islamism of the Khartoum regime rather than the logic of counter-insurgency and civil war, a potential in all societies" (Moses, 2006). Such framings of genocide that locate the causal variable of genocide within a regime or a society's ideologies-therefore-serve to locate the phenomenon of genocide within unfamiliar non-Western, non-liberal, or non-democratic ideologies, which in turn justifies the familiar over the unfamiliar, the liberal over the non-liberal, the democratic over the non-democratic, and the Western over the non-Western (see Hinton, 2012). The genocide prevention and humanitarian intervention movements that inherited this intellectual tradition, moreover, also employ a system of knowledge built around conceptions of good and evil, rather than a falsifiable relationship between the objective social conditions and subjective relations of people in conflict.

These connotations embedded within the concept of genocide make it exceedingly difficult for peacemaking practitioners, legal practitioners, and policy makers to use the word. Practitioners who attempt to prevent the kinds of mass violence that the word "genocide" is intended to signify often prefer, instead, to use the phrase "responsibility to protect" to denote the normative principle of preventing genocide, and the phrase "mass atrocity prevention" to denote the practical application of the genocide prevention norm (Evans, 2008; Rosenberg, 2009; Scheffer, 2006). By avoiding the word genocide and instead using the phrases "responsibility to protect" and "mass atrocity prevention," as Evans (2008), Rosenberg (2009), Scheffer (2006), and Weiss (2007) have pointed out in different ways, practitioners and policy makers have been able to avoid the rhetorical traps and reductionist connotations that "genocide," as a word, evokes. When scholars and policy makers frame a conflict as genocide, and then present genocide in the terms of a systematic theory of good and evil; express conceptions of genocide that locate genocide within the unfamiliar; and carry over the belief that genocide can only be stopped through external violence, external violence to stop genocide and topple totalitarian regimes is presented as just and necessary (see Moses, 2006, 2011b). From these starting points, to determine that a group is suffering genocide, and then to oppose using violence to protect the group, is often seen as taking the side of the perpetrators morally, and thus to side with evil. 


\subsection{Strategic Narratives and Genocide Discourses}

Strategic narratives, in shaping perceptions of conflicts to influence political behaviors, limit the opportunity for political contestation when they are accepted as social fact (Jackson, 2003; Mattern, 2005). This is especially so in genocide discourses that present complex conflict processes in good/bad binary terms, making the belief that a particular group is a "victim group" or a "perpetrator group" seem like a social fact (Subotić, 2016, p. 615). When the good/bad binary is laid over the victim/perpetrator binary, and combined with the sense that external violence is the only way to stop the perpetration of genocide, genocide discourses shut down critical analysis of a conflict. Strategic narratives reduce political space for debate by making alternative narratives sound incoherent and not compelling (Krebs \& Lobasz, 2007; Subotić, 2016, p. 615). The ability of genocide discourses to make it seem like a social fact that certain groups are good or bad intensifies this "lock-in effect" (Goddard, 2006). Dissenting points of view about how to act vis-à-vis the perpetrators or victims are presented as hopelessly naïve, at best, or morally evil at worst. This muddles the criteria necessary for making ethical judgments. The ability to know how to act and why, therefore, becomes obscured in this closed system of logic. As a result, the potential for actors to articulate moral arguments collapses into moralizing, while acting to stop genocide and to topple totalitarian regimes is taken as unquestionably good, and failing to do so as unquestionably bad. In such constructions, once the word genocide has been uttered, the moral judgement has already been made. This is what makes genocide discourses effective types of strategic narratives, directing political behaviors towards intervening against the perpetrator group, and presenting inaction in defense of the victims as a moral evil.

If genocide is an act that must be stopped, how should it be stopped? Many doubt that genocide can be ended peacefully because they assume that genocide is either a decentralized, pathological act with perpetrators at every level of society or an act impelled by the momentum of a huge bureaucratic enterprise beyond the control of anybody (Heidenrich, 2001, p. 95). When genocide is viewed in such terms, it appears that genocide is caused by either everyone in a society or no one. From this premise, an intellectual and conceptual holdover from the theory of totalitarianism, the only sanction against genocide is the application of external violence: war.

In seeing genocide as an evil act, one that is simultaneously committed by everyone and no one, the motives for the act collapse into the act itself. The killing of a group is seen as the reason why perpetrators kill the group. This tautology ascribes the beginning to the end, leaving the analyst to understand genocide not as political or sociological, but a type of sui generous violence. Preventing genocide is therefore about stopping those who will be killers from killing, not about understanding the ethical decisions people face in genocidal programs, the reasons why people lend their support to a genocidal program when they would otherwise stand opposed, why people remain bystanders, and how and why people make decisions to act upon their knowledge, either resisting or collaborating. The paradox is that genocide cries out for retribution, even generations later, because it is resistible, and not an indomitable phenomenon that can only be stopped by violence (Bronner, 1999, p. 318). The tragedy of reducing genocide to an inevitable evil is that the "all-encompassing evil of the holocaust" as with any other genocide, ironically "is precisely what demands a sense of nuance in making ethical judgments" (Bronner, 1999, p. 318).

\subsection{The Victims as Moral Innocents}

If the belief that external violence is the only means for preventing genocide is a pillar of the humanitarian intervention and genocide prevention traditions, then this belief generates a second pillar that affirms the assumptions of the first. This second pillar is that the victims of genocide are not parties in a conflict, but moral innocents guilty of neither wrong-doing, nor of inflicting any perceived injury upon their victimizers. The position is derived from an assumption in theories of totalitarian explained above. The victims, in such visions, are killed for no other reason than to advance the political, social, or utopian agendas of their killers (see Moses, 2011a). When the formulation is deployed in strategic narratives, it creates the belief that genocide ceases to be genocide when the victims are acting unethically, or when they are guilty of a crime or moral wrongdoing, or if they are in conflict with their victimizers. In other words, genocide cannot be committed against people who have done bad things to their aggressors -in such cases, those who are killed en masse are no longer thought of as victims of genocide, but casualties of war or civilian casualties.

Arendt's insistence in Eichmann in Jerusalem that no one or no group was ever completely innocent, when she pointed to the complicity of many individual Jews and the role of Jewish councils in aiding the German genocide, provoked intense backlash and led many to accuse her of blaming the Jews for their own fate (Arendt, 1963). Yet, she also argued that because no group deserved to have genocide committed against them, the attempt to destroy an entire group did render the group innocent in the sense that they were not guilty of a crime or offense that would have warranted their total annihilation as a group. To seek the extermination of German National Socialists, as a social group, after the war was to commit genocide. Thus, for Arendt, no group could ever deserve to have genocide committed against them no matter how bad their individuals were. The same was true in all cases of mass violence, Arendt argued, not just genocide. In totalitarian regimes such as the Soviet Union, which Arendt believed was not genocidal in ideology, "terror as 
we know it today strikes without any provocation [and] its victims are innocent even form the point of view of the persecutor" (Arendt, 1951/1973, p. 6). The arbitrariness of terror, where Bolshevik officials and police officers could become the victims of police terror, meant that "nobody, not even the executioners, can ever be free of fear". Even when those who were guilty of committing atrocities became the victims of the same atrocities, Arendt wrote, "the arbitrariness by which victims are chosen" meant that these individuals were "objectively innocent" regardless of what they may have done or not done (Arendt, 1951/1973, p. 6). Though the victims were objectively innocent, the victim group could not be morally innocent for Arendt. Yet, as the field of genocide studies developed its own theoretical literature, the distinction between moral innocence and objective innocence, the sense of being guilty of wrong doing, began it elide.

One of the seminal figures in the field, the sociologist Irving Louis Horowitz defines genocide as "a structural and systematic destruction of innocent people by a state bureaucratic apparatus" (Horowitz, 2002, p. 23). The word "innocent" is necessary in Horowitz's definition because it "sets [genocide] apart from other social evils", and recognizes that "the victim is 'punished' for being part of some particular group, tribe, race, or religion" (Horowitz, 2002, pp. 29-30). In Horowitz's perspective, genocide is a meaningful concept because it signifies an atrocity where the victims are targeted for no other reason besides their culturally-conditioned identity and are therefore "innocent" of any other wrong doing (Horowitz, 2002, pp. 23-28).

Similarly, Anderson and Anderson define genocide as "systematic, cold-blooded, bureaucratically administered extermination of entire ethnic, religious, or political groups by their own national governments in the absence of anything that a rational external observer could consider an adequate reason" (Anderson \& Anderson, 2013, p. 6). This suggests genocide could be considered a legitimate course of action if a rational outside observer determined the victims were guilty of some wrong doing. By definition, the authors continue, genocide is only committed against an imaginary enemy, not a real enemy. Thus, to eliminate a group that poses a real threat is not genocide. To "qualify" as genocide, the authors write, "a campaign must involve a systematic attempt to eliminate whole groups, including harmless 'critics', innocent families, and children, and suspect bystanders". The authors add that "merely eliminating actual political rivals is not genocide. It is unpleasant, but it is politics-as-usual, carried out everywhere" (Anderson \& Anderson, 2013, p. 7).

The problem here, as Martin Shaw has observed, is definitional and methodological. From a social scientific perspective, it is impossible to maintain that any given population can be purely perpetrator or purely victim, given that all social groups contain individuals who themselves have complex and changing roles within a conflict (Shaw, 2013, p. 36). Yet, in genocide scholarship (i.e., Anderson \& Anderson, 2013; Charny, 1994; Fein, 1993; Horowitz, 2002), and especially in genocide discourses employed by political activists or by nationalist or ethnic group actors, the perpetrator social group is presented as a coherent group defined by purely evil intentions while the victims are presented as passive recipients of violence, not actors or parties in conflict (Shaw, 2013 , p. 35). What is more, even in the most asymmetrical of conflicts, Shaw contends, individual victim-actors might be mostly people who are not perpetrators of violence against civilians, but the larger group to which they belong will inevitably include individuals who are. Yet, the "purity of the victims' victimhood is important not only for maintaining a simple 'perpetrator/victim' analytical model, but also for group 'ownership' of genocide". The idea of the "singular victim-groups", Shaw continues, "becomes a device policing communal identities" and "often of political institutions and causes which mobilize them" (Shaw, 2013, p. 36).

As this paper will argue in the next sections, the genocide discourses in America over ISIL genocides created a sense that the perpetrator group was purely and coherently evil which, in turn, ascribed that evil to every individual member of the social group. The conceptual holdovers from the theory of totalitarianism carried over into the genocide discourse, leading to a collective sense that only external violence could end the genocide. Because the social group was seen as a coherent collection of individuals, the strategic narrative that emerged was one that framed the prevention of genocide as requiring the extermination of the entire social group and all the individuals who were part of it-a policy response that itself is genocidal.

In regards to the conflict between Russia and Ukraine, a similar process is evident. For Ukrainian nationalists, Donald Beachler (2011, p. 150) writes, the notion of being the victims of genocide at the hands of Russian chauvinists decades ago provides Ukrainian actors with the ability to claim historical moral innocence, which is seen as legitimizing the Ukrainian position in the conflict for international and domestic audiences. Given the substantial Russian-speaking population in Ukraine, Ukrainian nationalist political leaders believe it is necessary to mobilize Ukrainian nationalist sentiments against Russia, as a country and ethnic community. The genocide discourse employed by Russian officials and state-backed media, in return, frames the Ukrainian government as supporting genocidal violence against ethnic Russians in Ukraine. The Russian government's claims against Ukraine, while spurious, are made in reference to this anti-Russian axiom of Ukrainian nationalism. From the perspective of the government in Moscow, this genocide discourse is also highly purposeful, presenting an image for domestic consumption that Ukraine and all ethnic Ukrainians are a coherent and malevolent group. This prescribes contentious and violent struggle as the only way for defending the good, while conferring a sense of historical and moral innocence on self-identified ethnic Russians. 


\section{Ukraine and Russia}

At least since the 2004 Orange Revolution, the Ukrainian nationalist movement, which is seeking to end Russian suzerainty in Ukraine, has dedicated a significant portion of its energies to proving that the Soviet treatment of Ukraine in the 1930 s and 1940 s constituted genocide (Beachler, 2011). In 2008, when Ukrainian President Viktor Yushchenko traveled to Canada, where a large Ukrainian diaspora carries significant influence, he carried two diplomatic goals: laying the ground work for Ukraine's entry into NATO and official recognition of the Holodomor, the great famine of 1932 and 1933, as genocide (Clark, 2008; Potter, 2008; Wood, 2008). Yushchenko-who was poisoned by dioxin in 2004 in an attack attributed to the Russian government-was one of the stalwarts of the Orange Revolution, leading a movement to strengthen Ukraine's ties to the West and break away from the influence of Russia. Within the context of this political movement, asserting that Stalin orchestrated a genocide in Ukraine in the 1930s become a powerful statement, mobilizing and legitimizing the nationalist movement by drawing a straight line between the direct control of Moscow over Ukraine in the Soviet Union in the 1930s and the Russian Federation's influence over Ukraine in the 2000s. The implicit claim was that Russian political, social, and economic dominance over Ukraine today is a direct consequence of the genocide of the 1930s, which brought Ukraine under the orbit of Moscow through a campaign of Russification. This genocide discourse sought to cast Ukrainians, as a group, as historical victims of Moscow to legitimize the nationalist movement's current efforts to economically and politically break away from Moscow and align Ukraine with the European Union (see Motyl, 2017).

When Yushchenko's successor Viktor Yanukovich was elected through the support of his of Russian-speaking political base, the Ukrainian government backed away from all claims that the Soviet Union had committed genocide in an attempt to "Russify" Ukraine. When Yanukovich was driven from power in popular protests in 2014, Russian troops invaded the country to secure Russian interests in the Donbas region and Crimea. The genocide discourse amongst Ukrainian political parties seeking to align the country with the European Union and NATO reemerged after the Russian annexation of Crimea in 2014, especially when evidence began to emerge that the new Russian-backed authorities in Crimea were marginalizing and dispossessing ethnic Tatar communities (Blank, 2015; Korostelina, 2015; Uehling, 2015). A growing number of Ukrainian leaders began to cite both the Holodomor and the 1944 genocide of the Crimean Tatars as evidence that the Russian Federation's invasion and support of rebels in the Donbas region and the annexation of Crimea were illegitimate because Moscow's dominance over these regions today is a consequence of the genocides in the 1930s and 1940s.

The Russian government responded by claiming Ukraine was plotting genocide today. The response was a text-book example of political elites crafting a strategic narrative to create public support for armed conflict, while promoting group cohesion. In a broad sense, political life depends on narratives, which individuals use to make sense of the world and their own identityposition within social groups (Somers, 1994), establishing the criteria by which individuals interpret political reality and create knowledge about how to act (Franzosi, 1998; Patterson \& Monroe, 1998). Narratives as such, however, are not spontaneous. Political actors-from individual elites to political parties, social movements, and governments-craft stories that influence people to act in certain ways or support certain policies. Political actors can invent narratives of historic victimization at the hands of a particular group in the past in order to justify political suppression, repression, or even mass violence against that group in the present. This dynamic is evident in cases of genocide, from the genocides of Native Americans to genocides in the former Yugoslavia, where political actors couch their attempts to annihilate a group not as a form of self-serving political gain, but as necessary for protecting society from that group (Bergholz, 2016; Madley, 2016; Naimark, 2002).

I argue that the introduction of genocide discourses in these types of strategic narratives can be a powerful motivator of such political and collective action. Genocide discourses within strategic narratives do not present conflicts as conflicts, but primordial struggles between good and evil, which directs political communities towards supporting polices of armed military interventions to suppress genocide. The claim that emerged from Russian government officials that Ukrainian nationalist actors were manufacturing a false history of Soviet genocides was used to present Ukrainian political actors as geo-political imposters and academic amateurs. The corresponding claim that it was Ukrainians who were using this imagined history to justify Ukrainian genocides against ethnic Russians in Ukraine was, in turn, a handy tool for creating a strategic narrative that positioned Ukrainians as deserving political repression. Indeed, the Russian invasion of Crimea and the Donbas region of Ukraine were framed by Moscow as attempts to defend ethnic Russian speakers-a large minority group in Ukraine-from ethnic cleansing and genocide at the hands of chauvinist Ukrainians who falsely demonized Russians as genocidaires and used them as a scapegoat to explain away the country's political and economic struggles (Weiss-Wendt, in press). ${ }^{1}$

As officials in the Russian government began accusing Ukrainians of inciting genocide against Russians, the Russian Foreign Ministry began efforts to thwart support amongst American activists and academics to rec-

\footnotetext{
${ }^{1}$ Weiss-Wendt (in press) cites "Russia Investigates Ukrainian Top Brass Over 'Genocide”", from the The Moscow Times (2 October 2014); and “Bastryrkin: Chislo postradvshikh ot voennykh prestuplenii kievskogo rezhima prevysilo 22000 chelovek", available at http://rusnext.ru/news/1454064729
} 
ognize the Holodomor as genocide. One tactic, designed to present Americans as hypocrites in front of Russian and Russian-speaking Ukrainian audiences, was to claim that the United States had no moral standing to accuse the Soviet Union of genocide in the past because white police officers in the United States kill so many black citizens (Weiss-Wendt, in press). In this sense, the Russian response to accusations of genocide in Ukraine were remarkably similar to the position taken by pro-Russian scholars and Russian diplomats during the brief war with Georgia in 2008 over the Abkhazia and South Ossetia regions, when they argued that Russia's military intervention in Georgia did not violate international law, but instead upheld the norms of the law because the war was an effort to protect the vulnerable ethnic Russian population from the Georgian governments' human rights violations and genocidal intentions. When challenged, they simply referred to Western intervention in Kosovo, Iraq, and Libya that were legitimized under slogans of genocide prevention and the responsibility to protect norm (Irvin-Erickson, 2017a; Rubenstein, 2017). The position coming from the Moscow government was surprisingly frank. If the United States and Western Europe could arbitrarily pick which group was an innocent victim of genocide (or a potential victim of genocide), to legitimize a foreign war in the name of the victims, then why couldn't Russia arbitrarily pick who to defend or not defend?

In 2015, the Russian justice department labeled Lemkin's (1953/2014) essay on the Soviet genocide in Ukraine, written in 1953, as "extremist literature", further escalating the war of words in the genocide discourse and officially censoring the writings of someone who is largely considered a human rights hero, but who is considered an anti-Russian chauvinist in Russia (IrvinErickson, 2017a, pp. 48-50; Russian Ministry of Justice, 2015; Weiss-Wendt, in press). This determination came at a time when academics in Ukraine, the United States, and Canada were beginning to discover Lemkin's writing on Soviet genocides in Ukraine, and the Holodomor. From the perspective of the Ukrainian nationalist movement, and its supporters from Ukrainian diasporas in Canada and the United States, positioning Ukraine collectively as a victim of genocide in the past would confer a sense of historical innocence on Ukraine as a country today, which could be translated into political capital in a geo-political struggle (Beachler, 2011, pp. 147-152). The Russian government tried to establish a counter narrative that negated the claims of victimhood by either drawing Ukraine and the West as morally equivalent to Russia or, better yet, positioning ethnic Russians in Ukraine as the innocent victims of the hypocritical aggressors in Ukraine and the West. The genocide discourse, from both sides of the conflict, sought to manipulate public sentiments about innocence and guilt through the language of genocide to legitimize certain positions in the armed conflict-with great effort amongst Ukrainian political movements to translate this into a stronger response from Western countries in support of the Ukrainian position, and attempts by Moscow to counter this moralizing discourse with a discourse of moral equivalency.

The Russian government's genocide narrativethough it did not persuade international audiences of Ukraine's illegitimacy-created a framework to promote group cohesion amongst the public in Russia and amongst Russian speakers in Ukraine to rally support for Russian military action and Moscow's political goals in Ukraine (Balzer, 2015). But these dynamics are not unique to the Russian government's attempts to rationalize an invasion of Ukraine. They are likewise on full display in attempts in the United States to understand and frame American conflicts in Iraq and Syria, and understand how to act.

\section{The United States and the Islamic State}

In the humanitarian intervention and genocide prevention traditions, witnesses and bystanders to genocide and mass atrocities are conceptualized as parties to the conflict-taking an implicit side against the victims by virtue of their self-perceived neutrality and their unwillingness or inability to act in defense of the victims (Charny, 2016, p. 8). The victims, meanwhile, are presented as not being parties to the conflict. Thus the conflict, in genocide, is presented as being between the perpetrators and the rest of humanity. Therefore-as an extension of this logical frame-the goal of the advocacy movement against genocide is to move state actors and international organizations from their neutral positions (which is seen as pitting them against the victims) into taking actions in defense of the victims, or to prevent and prosecute genocide.

A significant boost to the movement to intervene humanitarianly in defense of the victims of ISIL genocide came with a June 2016 determination by the UN Human Rights Council that genocide was being committed against Yezidis, a claim substantiated in a report to the UN Human Rights Council by the independent International Commission of Inquiry on the Syrian Arab Republic (Dieng \& Welsh, 2014, UN Doc. A/HRC/32/CRP.2). The finding gave spirit to movements to pressure states to officially recognize the genocide of Yezidis, with the goal of activating states' treaty-obligations under the UN Genocide Convention to protect civilians and prevent and prosecute the genocide (Kikoler, 2015; Stanton, 2015). There were also groups that wanted a legal determination of genocide in order to aid international efforts to resettle Yezidis as refugees. ${ }^{2}$ Christian groups in the United States were especially effective in mobilizing pressure on congressional representatives to pressure the State Department to include Christians as victims of ISIL genocide, in an effort to legitimize wide humanitarian protections and expansive refugee acceptance policies in the

\footnotetext{
2 For recent continuations of the argument, see Open Letter of Cross-Party British PMs to Home Secretary Amber Rudd, 17 November 2016, available at https://gallery.mailchimp.com/cbe8d3ab1c3cb6ca29607bbe2/files/1611_Iraqi_Religious_Minorities_Letter.pdf
} 
United States (Toosi, 2015, 2016). This movement culminated in a resolution before the House of Representatives, which passed unanimously, determining that ISIL was committing genocide against Christians and Yezidis (Congress, 2015). The determination that ISIL was committing genocide against Christians, in addition to Yezidis, became an important factor in the discourses employed by lobby groups in the United States who wanted to resettle ISIL victims in the United States as refugees (Knights of Columbus \& In Defense of Christians, 2016).

However, the genocide discourse to recognize the Christian victims of ISIL genocides emerged from within the context of a larger strategic narrative taking shape in the United States, which was placing increasing pressure on President Obama's administration between 2015 and 2016 to frame United States foreign policy and humanitarian policy in group-selective religious terms. The inclusion of Christians as victims of genocide along with the Yezidis, in the context of this second genocide discourse, created a problem for the Obama administration. With the emergence of a growing genocide discourse that was not orientated towards changing United States foreign policy to expand humanitarian relief to victims, but rather to orientate United States policy towards eradiating ISIL militarily, any statement that genocide was being committed only against Yezidis and Christians would appear to be disregarding the deaths of Muslims at the hands of ISIL. The Obama administration faced a dilemma. To include Christians and Yezidis as the only recognized victims of genocide would make it appear that the United States was drawing a distinction between the victims of ISIL violence, to suggest that the deaths of Muslims were not as morally reprehensible as the deaths of non-Muslims. This was despite the fact that individuals from all religious groups were dying brutally at the hands of ISIL fighters, in the same conflict-and despite the fact that the genocide discourse employed by Catholic lobby groups was intended to use a common Christian identity to expand humanitarian sentiments amongst Western Christians to all victims of ISIL violence.

Yet, including Muslims as the victims of ISIL genocides-in the perspective of many-would be tantamount to denying the genocide against Yezidis and Christians, or tantamount to denying that ISIL was genocidal. Before exploring why, it is worth noting that this put the Obama administration in a political bind. With pressure mounting on the Obama administration, the United States Department of State attempted to finesse the dilemma, and determined that ISIL was committing genocide in Syria and Iraq against Yezidis, Christians, and Shia Muslims (Kerry, 2016). Secretary of State John Kerry (2016) included Shiite Muslims in his official statement, noting that the Islamic State was seeking to "cleanse the land of [Shiite] filth". But he conveniently left out Sunni Muslims as victims of ISIL genocide-even though Sunni Muslims were being killed by ISIL in much the same manner as the other victims. If the list of victims could be expanded to include these different religious minorities, why not add Kurds and Sunnis to the list of ISIL victims of genocide, as well?

The absence of Sunnis as a victim of ISIL genocide within the genocide discourse implies that, because ISIL is based geographically in historically Sunni Arab lands, and because it is a self-proclaimed Sunni movement, its victims of genocide would not be Sunni. ISIL fighters and leaders might target Sunnis for death and terror, according to this logic, but not genocide. This is despite the fact that a majority of the cities and towns destroyed, and the millions of people displaced, by ISIL violence are Sunni. Human rights monitors have documented ISIL enslavement, rape, massacre, and kidnapping of Sunni victims - the same kinds of atrocities ISIL has committed against members of all other groups (Sly, 2016; Tayler, 2017; Wille, 2016a). This genocide discourse, which removes Sunnis from being recognized as victims of ISILS genocide, implies that Sunni Muslims are a monolithic group, where the atrocities committed by Sunni actors (ISIL) impugns the whole group of Sunni Muslims. Thus, Sunni Muslims become collectively guilty of ISIL attempts to destroy entire groups-guilty of genocide. Likewise, for those who advocate for a narrative that ISIL is committing genocide against Christians and Yezidis, and thus leave out Muslims as victims of genocide, the ISIL targeting of all Muslims is not presented as genocide. The reasoning is simple. The axiom of the genocide discourse that demands that the victims of genocide must be moral innocents and the perpetrators morally bad creates a situation where one group cannot commit genocide against themselves. Thus, from this discursive framing, to claim that Sunnis were both victims and perpetrators of genocide against Sunnis is nonsensical. The notion that the victim group is also the perpetrator group invalidates the notion that the victim group is morally innocent-which means, according to this frame, that they cannot be the victims of genocide. Likewise, to view ISIL genocides as a genocide of Muslims against Yezidis and Christians excludes Muslims from ranks of victims of genocide.

The framing of the violence as such, to suggest that Sunnis cannot be the victims of ISIL genocide (because ISIL is a Sunni group), or that Muslims cannot be the victims of ISIL genocide (because ISIL is a Muslim group), is social scientifically unsound and politically dangerous. The framing sets in motion a discourse of placing collective blame for ISIL violence on Sunni Islam, or all of Islam (Tayler, 2017; Wille, 2016b). If Muslims are the perpetrators of genocide, then their victims-Yezidis, Christiansare moral innocents, which confers upon the perpetrator a corresponding sense of evil intrinsic to their group identity. The attempt by the Obama administration to finesse the problem and list Shia Muslims as victims, therefore, did not change the fundamental axioms of the genocide discourse, but only reified the reductionist tendency of genocide discourses to collapse the complexities of the conflict into simple calculations of good and evil. Within a year, it would therefore be possible to discern a clear genocide discourse in the United States that advocated 
exterminating ISIL, and presented ISIL as an intrinsically evil social group of radical Islamists, or even an evil social group of all Muslims. Calls to exterminate ISIL, or radical Islamists, or even all Muslims, were therefore presented not as genocide, but a form of social protection against the threat of genocide posed by this group (with some suggesting the genocidal threat was posed by ISIL, others arguing it was posed by radical Sunni Islamists, and others still citing Islam as the genocidal threat). What is more, when genocide becomes the operative lens through which ISIL (or Sunnis, or Islam) was conceptualized, then the prevention of genocide is not seen as involving the resolution of differences between groups because there can be no resolution between good victims and bad perpetrators. Sociological or political projects that deal with the implications of identity that underscore intergroup conflicts and genocidal processes were likewise dismissed as naïve, since it was (is) believed that there is no group conflict to resolve. The solution, rather, was seen as applying external violence to sweep away the genocidal threat posed by ISIL (or Sunnis, or Islam).

The public discourse and the policy conversations in the United States about how to respond to ISIL, therefore, were no more sophisticated than the essentialist discussions of anti-totalitarianism in generations past. In presenting ISIL as evil, an evil that is simultaneously engendered by every Sunni and no one in particular, the motives for ISIL violence collapse into the violence itself. The tautology that took hold in strategic narratives in the United States undermined any kind of coherent attempt to respond to the violence in political or sociological terms. Preventing ISIL violence, therefore, was about stopping those who will be killers from killing, not about understanding the ethical decisions people face, the reasons why people lend their support to ISIL's genocidal program when they would otherwise stand opposed, why people remain bystanders, why they find they cannot resist, and how and why people make decisions to act upon their knowledge, either resisting or collaborating to different degrees.

With the construction of an all-encompassing evil Islamic enemy, movements in the United States to increase the number of refugees accepted into the United States, and efforts to expand humanitarian relief by forcing the United States to officially recognizes that ISIL was committing genocide, collapsed. The initial movements deploying a genocide discourse to motivate broad and inclusive humanitarian responses gave way to a strategic narrative that cast the perpetrator group as intrinsically evil, and sought to legitimize greater uses of American military power in Syria and Iraq in the name of confronting evil. Thus the genocide discourse that prevailed in the United States argued against accepting victims of ISIL genocide as refugees for fear that their children, as members of an intrinsically evil group, might be sympathetic to ISIL or radical Islam. The organizing framework for collective action became one of orientating United States foreign policy around specifically Christian interests, coupled with calls to violently eradicate ISIL as a social group as the only solution to the genocides committed by ISIL. With the genocide discourse underpinning these frameworks, the ability for American policy makers, leaders, and civil society movements to think clearly or ethically about the conflict eroded.

The efforts of George W. Bush to combat a tendency to frame United States foreign policy in religious terms have been well-documented. In his now-famous address on 17 September 2001 at the Islamic Center of Washington, DC, Bush sought to prevent United States foreign policy from being perceived as being at war with a religion, and address a rise in anti-Muslim hate crimes in the country in the wake of the 11 September terrorist attacks. ${ }^{3}$ Likewise, the Obama administration and Secretary of State John Kerry worked to ensure United States foreign policy could not be construed as being anti-Islam (Kerry, 2014). But the intervening years between 2001 and 2016 saw an awakening of a popular movement across American society to position United States foreign policy in explicitly Christian terms-despite 16 years of efforts from the country's political elites from both major parties to stem this trend. By the second Republican Party primary presidential debate on 16 September 2015, the mood of the nation had shifted dramatically. ${ }^{4}$

During the debate, a consensus emerged amongst the candidates that Islam was an existential threat to Western civilization. This consensus took on a feeling of urgency with the prospect of nuclear-armed Iran and the rise of ISIL. While the candidates were careful to only say they would fight against "radicals", their rhetorical construction of Western civilization as Jewish and Christian placed all of world-Islam outside the boundaries of the Western, the American, and the "us". One prevalent narrative in the United States is that American foreign policy should stand in defense of "Western civilization". The strategic narrative creates a sense of coherence in what would otherwise be an arbitrary determination about who is a friend and who is an enemy, and which societies are desirable to include within the American security community and which are necessary to exclude (Jackson, 2003). Thus all Islam became implicitly radical, a world-force excluded from the West that must be combated. The message affirmed the candidates' antiMuslim credentials to those who would vote solely on anti-Muslim grounds, while allowing the candidates to plausibly deny any such prejudice to the general American public. The fact that ISIL and Iran were in conflict with each other, positioned on antagonistic geopolitical poles, was irrelevant within the strategic narrative that

\footnotetext{
${ }^{3}$ The video and transcript is archived by the Berkley Center for Religion, Peace, and World Affairs at Georgetown University, available at https:// berkleycenter.georgetown.edu/quotes/george-w-bush-on-islam-and-terrorism-3

${ }^{4}$ All citations to the debate come from Time, "Transcript: Read the Full Text of the Second Republican Debate, September 16, 2015", available at http://time.com/4037239/second-republican-debate-transcript-cnn
} 
positioned both actors as united in their opposition to America and the "West". Also irrelevant was any meaningful distinction between the strategic goals of these different actors and acts of violence, so that any terrorist threat to the United States posed by ISIL was presented as being an expression of their genocidal conduct, and part of a larger Muslim plot to destroy America. Thus, an outside observer might draw objective distinctions between an act of terrorism and an act of genocide, but the presidential candidates had forged a narrative where an act of terrorism committed against the United States by an Islamic actor would necessarily be a reflection of a "radical Islamic" genocidal objective.

American voters had every reason to worry about nuclear weapons falling into the hands of a government in Iran whose leaders have denied the Holocaust and called for the destruction of the Jews of Israel. But this was not the argument being made. Instead, the candidates likened the struggle to prevent a nuclear-armed Iran to a struggle between two civilizations with destinies structured like a zero-sum game, the Jewish and Christian West versus the Islamic other. Towards the end of the three-hour debate, John Kasich-who along with Jeb Bush urged tolerance and defended the principles of an individual human rights based approach to world affairs-evoked the memory of the Holocaust directly, saying: "One more time in America, we need to revive the concept of citizenship, where everybody's actions make a huge difference in changing the world. We have a Holocaust memorial on our state house grounds. And there is one line on there that stands out all the time: 'If you've saved one life, you've changed the world'". In the 16 September debate, Kasich likened the Nazi German attempt to destroy the Jews to the threat posed to Western civilization by a nuclear-armed Iran and radical Islamic terrorists. The timing of the reference to the Holocaust was opportune in the debate, imbuing a sense of moral purpose into his call that America revive a unified concept of citizenship. But the sentence also harkened back to something he had said two sentences earlierthat America had to rebuild relationships with "our allies" so that, united, "we'll fight for freedom and for human rights". To the casual listener, Kasich was speaking in the usual platitudes of the Holocaust as a lesson about defending citizenship and human rights. But he had already asserted that the Iran nuclear agreement would be a positive force in world affairs because it would allow for the "military option" if "we find out that they may be developing a nuclear weapon". And, at the same time, he added, the agreement provides a framework for working with allies in "Western civilization, our friends in Europe", to restrain Iranian geopolitical ambitions. The fight for revitalizing citizenship and human rights that Kasich infused with moral purpose through his reference to the Holocaust was therefore bound up within the struggle against Iran (and vice-versa), which ultimately demanded the unity of Western civilization to face this Islamic threat to its existence. What was this thing Kasich was calling Western civilization? Whatever it was, he saw it as Jewish and Christian.

This sentiment was soon echoed by Mike Huckabee, who claimed that the Iran deal "is really about the survival of Western civilization". A nuclear Iran, the former governor of Arkansas concluded, threatens "the very essence of Western civilization". Later, Kasich went on to explain his theory of world affairs, linking together the Iranian regime and ISIL into one coherent threat to the United States, stating that "Western civilization, all of us, need to wake up to the fact that those murderers and rapists need to be called out, and in Western civilization we need to make it clear that our faith in the Jewish and Christian principals force us to live a life bigger than ourselves". Through this context, what Kasich meant by his reference to the Holocaust became clear, and tangible. The Holocaust was a benchmark that the American public should use to measure the threat that Iran and ISIL pose to the existence of the West. It was a strategic narrative that collapsed distinctions between different Sunni movements, between Sunni and Shia groups, between state adversaries and non-state actors, into a single category of Islam set in a genocidal struggle against the West. The genocide discourse Kasich deployed-although it advocated for an inclusive, and human-rights based reference point to orientate a compassionate United States foreign policy-contained the seeds of its own demise. Kasich's construction of a Judeo-Christian West that was fundamentally good, in the context of the genocide discourse he set forth, allowed for the silent implication that the Muslim Middle East was intrinsically evil. This-in the debate an in the wider public discourse-allowed for the rise of a new genocide discourse that undermined Kasich's own human-rights based policy prescriptions.

What were Kasich's unstated assumptions about Islam embedded in the statement? Firstly, Western civilization was Jewish and Christian. And, by extension, "radical" Islam would have no place in a world that was safe for Jewish and Christian civilization. Secondly, in so far as Jewish and Christian principles allowed for individuals to "live a life bigger than ourselves", Islam would drive people down into something less, thus fulfilling the prior expectation that Islam had no place in a world safe for "us". Kasich's human rights based position, therefore, could not separate itself from the non-human rights based approach advocated by Huckabee, which opened the door for Ted Cruz to promise to kill all of the radical Islamists in the world. Ben Carson had already said in the first debate that he would ignore the Geneva Conventions and torture Islamic enemies of the United States, and a few days later he suggested that a Muslim would be unqualified to be president of the United States because a Muslim, by virtue of his group membership, could not share American values (Bradner, 2015). ${ }^{5}$ The rhetoric of these

\footnotetext{
${ }^{5}$ See Time, "Transcript: Read the Full Text of the Primetime Republican Debate, August 6, 2015", available at http://time.com/3988276/republicandebate-primetime-transcript-full-text
} 
four politicians-Kasich, Huckabee, Carson, and Cruzwas highly purposefully, categorically collapsing world Islam into ISIL, and thereby into genocidal terror. They were not against Islam, but against radical Islam. Yet they had constructed a vision of Islam that presented all Islam as essentially radical, as a monolithic group that exists outside of the boundaries of the West, whose existence in the world posed an existential threat to the existence of Western civilization, which was Jewish and Christian. In this genocide discourse, which effectively prevented clear and ethical thinking, it became impossible to distinguish Kasich's nuanced and moral position from the blunt moralizing of the larger strategic narrative taking shape.

This second genocide discourse, as a "bottom-up" narrative emanating from political activists in United States civil society that was picked up and articulated by political elites such as Huckabee and Cruz, succeeded in defining the terms of engagement with United States foreign policy against Islam. The movement eventually found a political articulation in the eventual Republican nominee, and later United States president, Donald Trump, who embraced the discourse of Muslim genocides being committed against Christians, and linked ISIL, al Qaeda, Hamas, and Hezbollah into a single genocidal movement (Fredericks, 2016; Trump, 2017); called for a ban on all Muslims entering the United States and immediately attempted to partially enact that ban in his first month in office (Fields, 2015); selected a National Security Advisor who believed Islam was a political ideology and that the United States was at war with Islam (Kaczynski, 2016); appointed a top advisor who believed the United States had a duty to reject secularism and eradicate Islam from United States society while combatting Islam overseas (Harkinson, 2016; Mallin, 2017); and unapologetically stated that the United States should privilege accepting Christian refugees because the secondgeneration of Muslim immigrants in the United States could become terrorists, and then rejected accepting all refugees from Muslim countries on the grounds that some of the Christians might be Muslims who, though they are victims of ISIL today, would produce future decedents of Muslims who would be terror threats because they were Muslims (Brody, 2017; Memoli, 2016). In so doing, the genocide discourse of ISIL genocides established, discursively, an image of an American political community as a distinctly Christian community-Christian in its values and goals, and in the stakes of its international and domestic struggles-without having to define the content of that identity, define what it meant to be Christian or American, or think clearly about what a "Christian" or "American" ethics would look like in the face of the challenge of responding to genocide. The honest and inclusive attempts to employ a genocide discourse that used a Christian identity to bridge sympathy between Americans and ISIL victims of genocide and increase the number of refugees accepted into the United States thereby gave way, over the course of two or three years, to a strategic discourse that brought about its very antithesis.

\section{Conclusions}

Politically, the strategic narratives I have termed genocide discourses are highly effective in legitimizing certain kinds of political actions - from legitimizing certain wars to guiding decisions about which parties in local or regional conflicts should be supported by powerful countries. Such narratives simultaneously cast the perpetrators as evil, the victims as innocent, and prescribe external violence as the only means of defending the good. In the context of United States foreign policy, the effect is to place Sunnis (or all Muslims) beyond what Helen Fein (1993, p. 59) termed "the universe of moral obligation" of a Christian American community and foreign policy. In the context of Iraqi politics, the genocide discourse also reifies the sentiments of Shiite officials in the Iraqi government who have a material interest in socially and politically marginalizing Sunni groups and casting the stakes of political struggle in Iraq in religious terms. In both cases, the strategic narratives that deploy the concept of genocide to describe the actions or identity of the other reify themselves in a self-fulfilling prophesy, helping create the social conditions that serve as evidence of their existence (Cobb, 2013, p. 4)-evidence that the social, political, and moral constellation of the human universe really is divided along a Christian/Muslim axis (or a Shia/Sunni axis). But it also sets in motion the kinds of reductionist thinking that locates the criteria for ethically judging responses to actions within the act that must be judged. Because ethics presupposes the ability to make a choice-and genocide discourses are designed to remove the sense that one has a choice-the genocide discourses explored in this article push elected officials, policy makers, and the public more generally in America and Russia towards inserting themselves into a violent conflict on behalf of particular parties, while casting the American and Russian positions in conflicts as the side of the good.

A kind of reciprocal annihilation becomes the imagined solution to genocide, in so far as the total annihilation of a supposedly evil social group is presented as the only way to prevent the total annihilation of a supposedly pure and innocent victim group. In the context of the conflict in Ukraine sparked by the clandestine Russian invasion of Crimea and the Donbas region, the argument amongst Ukrainian nationalists that Soviet genocides were an attempt to "Russify" Ukraine in order to subject Ukraine to the political authority of Moscow legitimizes and grounds calls to remove Russian influences from Ukraine as a solution to Ukraine's political and economic problems (Motyl, 2017). Likewise, the prevarications from Moscow about Ukrainian genocides against ethnic Russians are effective tools for conjuring up domestic support for an aggressive foreign war and annexing large portions of Ukraine (Motyl, 2017, p. 360).

In the context of United States politics, the genocide discourses are operating in much the same way, calling to mind solutions to genocides in Iraq and Syria that rely 
on reductionist and essentialist thinking about parties in conflict. Such genocide discourses frame external violence deployed against ISIL (or Sunni Muslims, or even all of Islam) as a regenerative force-a source of grace in defense of the innocent-that can bring peace out of genocide. What drops out of political discourse, and what drops out of the movements and policies they inspire, is any serious conversation about the ethics and efficacy of such interventions, or any thought about how peace is supposed to be forged after wiping away the totalitarian/genocidal ISIL movement. The same can be said for Ukrainian and Russian accusations of each other as genocidal. This is because, in eliminating the social group that seeks to eliminate entire social groups, the promise of peace is not believed to be located in the political and social realms of conflict. Rather, the promise of peace itself is taken as implicit in the morally sanctioned violence that purifies society of sources of evil.

\section{Acknowledgements}

Publication of this article was funded in part by the George Mason University Libraries Open Access Publishing Fund. An early version of this article was presented at the International Studies Association's 58th Annual Convention in Baltimore, Maryland, in the United States, on 22-25 February 2017. My co-panelists, Alexander D. Barder, Benjamin Meiches, Ernesto Verdeja, and Louise Wise offered thoughtful comments. Thank you to Richard H. King for reading the manuscript and greatly improving the final product. Thank you, also, to Stephen Eric Bronner and to my anonymous peer reviewers who gave valuable feedback. Of course, any errors or deficiencies are mine.

\section{Conflict of Interests}

The author declares no conflict of interests.

\section{References}

Anderson, E. N., \& Anderson, B. A. (2013). Warning signs of Genocide: An anthropological perspective. Lanham, MD: Lexington Books.

Arendt, H. (1973). The origins of totalitarianism. New York, NY: Harcourt Press. (Original work published 1951)

Arendt, H. (1963). Eichmann in Jerusalem: A report on the banality of evil. New York, NY: Viking Press.

Arendt, H. (1970). On violence. New York, NY: Houghton Mifflin.

Balzer, H. (2015). The Ukraine invasion and public opinion. Georgetown Journal of International Affairs, 16(1), 79-93.

Beachler, D. W. (2011). The Genocide debate: Politicians, academics, and victims. New York, NY: Palgrave Macmillan.

Bergholz, M. (2016). Violence as a generative force: Iden- tity, nationalism and memory in a Balkan community. Ithaca, NY: Cornell University Press.

Blank, S. (2015). A double dispossession: The Crimean Tatars after Russia's Ukrainian War. Genocide Studies and Prevention: An International Journal, 9(1), 18-32.

Bradner, E. (2015, September 27). Ben Carson again explains concerns with a Muslim President. CNNPolitics. Retrieved from http://www.cnn.com/2015/09/ 27/politics/ben-carson-muslim-president-sharia-law

Brody, D. (2017, January 30). The full interview: President Trump talks with CBN's David Brody. Christian Broadcasting Network News. Retrieved from http:// www1.cbn.com/cbnnews/politics/2017/january/jud ge-gorsuch-a-dream-pick-for-supreme-court

Bronner, S. E. (1999). Making sense of hell: Three meditations on the Holocaust. Political Studies, 47(2), 314-328.

Charny, I. W. (1994). Toward a generic definition of Genocide. In G. J. Andreopoulos (Ed.), Genocide, conceptual and historical dimensions (pp. 64-94). Philadelphia, PA: University of Pennsylvania Press.

Charny, I. W. (2016). The Genocide contagion: How we commit and confront Holocaust and Genocide. Lanham, MD: Roman and Littlefield.

Clark, C. (2008, May 27). Harper Government moves to recognize 1932-33 Ukrainian famine as Genocide. The Globe and Mail. Retrieved from http://www. theglobeandmail.com/news/national/harper-govern ment-moves-to-recognize-1932-33-ukrainian-famine -as-genocide/article673366

Cobb, S. B. (2013). Speaking of violence: The politics and poetics of narrative dynamics in conflict resolution. Oxford: Oxford University Press.

Congress. (2015). Expressing the sense of Congress that the atrocities perpetrated by ISIL against religious and ethnic minorities in Iraq and Syria include war crimes, crimes against Humanity, and genocide. Congress.gov. Retrieved from https://www.congress. gov/bill/114th-congress/house-concurrent-resolution /75/related-bills

Dieng, A., \& Welsh, J. (2014, August). Statement by Adama Dieng, special adviser of the SecretaryGeneral on the prevention of genocide, and Jennifer Welsh, special adviser of the Secretary-General on the responsibility to protect, on the situation in Iraq. Retrieved from http://www.un.org/en/prevent genocide/adviser/pdf/2014-08-12.Statement\%20of \%20the\%20Special\%20Advisers\%20on\%20Iraq.pdf

Evans, G. (2008). Responsibility to protect: Ending mass atrocity crimes once and for all. Washington, DC: Brookings Institution Press.

Feierstein, D. (2013). Beyond the binary model: National security doctrine in Argentina as a way of rethinking Genocide as a social practice. In A. L. Hinton, T. LaPointe, \& D. Irvin-Erickson (Eds.), Hidden Genocides: Power, knowledge, memory (pp. 68-80). New Brunswick, NJ: Rutgers University Press. 
Fein, H. (1993). Genocide: A sociological perspective. London: Sage.

Fields, M. (2015, December 7). Donald Trump calls for "complete shutdown of Muslims entering the United States". Breitbart. Retrieved from http://www. breitbart.com/big-government/2015/12/07/trumpcalls-complete-shutdown-muslims-entering-unitedstates

Franzosi, R. (1998). Narrative analysis: Or why (and how) sociologist should be interested in narrative. Annual Review of Sociology, 24, 517-554.

Fraenkel, E. (2017). The dual state: A contribution to the theory of dictatorship. New York, NY: Oxford University Press. (Original work published 1941)

Fredericks, B. (2016, August 16). Trump calls for end of "absolute and total Genocide". New York Post. Retrieved from http://nypost.com/2016/08/16/trumpcalls-for-end-of-absolute-and-total-genocide-by-isis

Freedman, L. (2006). The transformation of strategic affairs. Abingdon; NY: Routledge for the International Institute for Strategic Studies.

Goddard, S. E. (2006). Uncommon ground: Indivisible territory and the politics of legitimacy. International Organization, 60(1), 35-68.

Harkinson, J. (2016, September 15). Trump campaign CEO was a big promoter of anti-Muslim extremists. Mother Jones. Retrieved from http://www. motherjones.com/politics/2016/09/stephen-bannon -donald-trump-muslims-fear-loathing

Heidenrich, J. G. (2001). How to prevent Genocide: A Guide for policymakers, scholars, and the concerned citizen. Westport, CT: Praeger.

Hinton, A. L. (2012). Critical genocide studies. Genocide Studies and Prevention: An International Journal, 7(1), 4-15.

Horowitz, I. L. (2002). Taking lives: Genocide and state power (5th ed.). New Brunswick, NJ: Transaction.

lakovou, V. (2009). Totalitarianism as a non-state: On Hannah Arendt's debt to Franz Neumann. European Journal of Political Theory, 8(4), 429-447.

Irvin-Erickson, D. (2017a). Protection from whom? Tensions, contradictions, and potential in the responsibility to protect. In E. D. Jacobs (Ed.), Rethinking security in the twenty-first century (pp. 105-124). New York, NY: Palgrave.

Irvin-Erickson, D. (2017b). Raphaël Lemkin and the concept of Genocide. Philadelphia, PA: University of Pennsylvania Press.

Jackson, P. T. (2003). Defending the West: Occidentalism and the foundation of NATO. Journal of Political Philosophy, 11(3), 223-252.

Kaczynski, A. (2016, November 22). Michael Flynn in August: Islamism a "vicious cancer" in body of All Muslims that "has to be excised". CNNPolitics. Retrieved from http://www.cnn.com/2016/11/22/ politics/kfile-michael-flynn-august-speech

Kerry, J. (2014). Statement on the situation in Iraq. US State Department. Retrieved from https://2009- 2017.state.gov/secretary/remarks/2014/08/230401. htm

Kerry, J. (2016). Remarks on Daesh and Genocide. US State Department. Retrieved from https://20092017.state.gov/secretary/remarks/2016/03/254782. htm

Kikoler, N. (2015). Our generation is gone: The Islamic State's targeting of Iraqi minorities in Ninewa. Washington, DC: United States Holocaust Memorial Museum. Retrieved from https://www.ushmm.org/ $\mathrm{m} / \mathrm{pdf}$ /Iraq-Bearing-Witness-Report-111215.pdf

Knights of Columbus \& In Defense of Christians. (2016, March 9). Genocide against Christians in the Middle East (Report Submitted to Secretary of State John Kerry). Retrieved from http://www.stop thechristiangenocide.org/en/resources/Genocidereport.pdf

Kornat, M. (2006). Polish interpretations of Bolshevism and totalitarian systems (1918-1939). In J. W. Borejsza \& K. Ziemer (Eds.), Totalitarian and authoritarian regimes in Europe: Legacies and lessons from the twentieth century (pp. 80-105). New York, NY: Berghahn Books.

Korostelina, K. (2015). Crimean Tatars from mass deportation to hardships in occupied Crimea. Genocide Studies and Prevention: An International Journal, 9(1), 33-47.

Krebs, R. R., \& Lobasz, J. K. (2007). Fixing the meaning of 9/11: Hegemony, coercion, and the Road to war in Iraq. Security Studies, 16(3), 409-451.

Kuperman, A. J. (2008). The moral hazard of humanitarian intervention: Lessons from the Balkans. International Studies Quarterly, 52(1), 49-80.

Lemkin, R. (1944). Axis rule in occupied Europe: Laws of occupation, analysis of government, proposals for redress. Washington, DC: Carnegie Endowment for International Peace.

Lemkin, R. (2014). Soviet genocide in the Ukraine. Kingston: Kashtan Press. (Original work published 1953)

Madley, B. (2016). An American Genocide: The United States and the California Indian catastrophe. New Haven, CT: Yale University Press.

Mallin, A. (2017, February 1). What unearthed radio recordings tell us about Steve Bannon's worldview. $A B C$ News. Retrieved from http://abcnews.go.com/ Politics/steve-bannon-fire-past-comments-islam/sto ry?id $=45193278$

Mattern, J. B. (2005). Ordering international politics: Identity, crisis, and representational force. New York, NY: Routledge.

Memoli, M. A. (2016, September 19). Donald Trump warns of more attacks and boasts that he "called" bombing in New York. Los Angeles Times. Retrieved from http://www.latimes.com/nation/politics/trail guide/la-na-trailguide-updates-donald-trump-warns -of-more-attacks-and-1474286542-htmlstory.html

Moix, B. (2016). Turning atrocity prevention inside-out: 
Community-based approaches to preventing, protecting, and recovering from mass violence. Genocide Studies and Prevention: An International Journal, 9(3), 59-69.

Moses, A. D. (2006). Why the discipline of "genocide studies" has trouble explaining how genocides end. The Social Science Research Council. Retrieved from http://howgenocidesend.ssrc.org/Moses

Moses, A. D. (2011a). Historiographical review: Paranoia and partisanship: genocide studies, holocaust historiography, and the 'apocalyptic conjuncture'. The Historical Journal, 54(2), 553-583.

Moses, A. D. (2011b). Revisiting a founding assumption of genocide studies. Genocide Studies and Prevention: An International Journal, 6(3), 287-300.

Motyl, A. (2017). Ukraine vs. Russia: Revolution, democracy and war. Washington, DC: Westphalia Press. Naimark, N. (2002). The fires of hatred: Ethnic cleansing in twentieth-century Europe. Cambridge, MA: Harvard University Press. Neumann, F. L. (1942). Behemoth: The structure and practice of national socialism, 1933-1944. Chicago, IL: Ivan R. Dee.

Neumann, S. (1942). Permanent revolution: The total state in a world at war. Manhattan, NY: Harper \& Brothers.

Patterson, M., \& Monroe, K. R. (1998). Narrative in political science. Annual Review of Political Science, 1, 315-331.

Potter, M. (2008, May 25). President to start his visit at Ukraine famine memorial. Toronto Star. Retrieved from https://www.thestar.com/news/2008/05/25/ president_to_start_his_visit_at_ukraine_famine_me morial.html

Rosenberg, S. P. (2009). Responsibility to protect: A framework for prevention. Global Responsibility to Protect, 1(4), 442-477.

Rosenberg, S. P., Galis, T., \& Zucker, A. (Eds.). (2016). Reconstructing atrocity prevention. New York, NY: Cambridge University Press.

Rubenstein, R. E. (2017). State security, human security, and the problem of complementarity. In E. D. Jacobs (Ed.), Rethinking security in the twenty-first century (pp. 225-244). New York, NY: Palgrave.

Russian Ministry of Justice. (2015). Federalnyi spisok ekstremistskikh materialov: 3151 [On countering extremist activity]. Russian Ministry of Justice. Retrieved from http://minjust.ru/extremist-materials ?field_extremist_content_value=\%D0\%BB\%D0\%B5\% D0\%BC\%D0\%BA\%D0\%B8\%D0\%BD

Scheffer, D. (2006). Genocide and atrocity crimes. Genocide Studies and Prevention: An International Journal, 1(3), 229-250.

Seimas of the Republic of Lithuania. (2015). Resolution on the Genocide of Christians and other religious minorities in the Middle East and North Africa (Res. No. XII-2177. §). Vilnius: Seimas of the Republic of Lithuania

Shaw, M. (2013). Genocide and international relations:
Changing patterns in the transitions of the late modern world. Cambridge: Cambridge University Press.

Sly, L. (2016, November 23). ISIS: A catastrophe for Sunnis. Washington Post. Retrieved from http:// www.washingtonpost.com/sf/world/2016/11/23/isis -a-catastrophe-for-sunnis

Smith, R. M. (2003). Stories of peoplehood: The politics and morals of political membership. Cambridge: Cambridge University Press.

Söllner, A. (2004). Hannah Arendt's The Origins of Totalitarianism in its original context. European Journal of Political Theory, 3(2), 219-238.

Somers, M. R. (1994). The narrative constitution of identity: A relational and network approach. Theory and Society, 23(5), 605-649.

Spiro, H. J., \& Barber, B. R. (1970). Counter-ideological uses of "totalitarianism". Politics and Society, 1(1), $3-21$.

Stanton, G. H. (2015, October 14). ISIS is committing Genocide. Genocide Watch. Retrieved from http:// genocidewatch.net/2015/10/15/isis-is-committinggenocide-2

Subotić, J. (2016). Narrative, ontological security, and foreign policy change. Foreign Policy Analysis, 12(4), 610-627.

Tayler, L. (2017, February 3). Victimized first by ISIS, then by the Liberators. Human Rights Watch. Retrieved from https://www.hrw.org/news/2017/02/ 03/victimized-first-isis-then-liberators

Toosi, N. (2015, December 9). Christians press U.S. to call ISIL violence "Genocide". Politico. Retrieved from http://www.politico.com/story/2015/12/christianspush-label-islamic-state-genocide-216596

Toosi, N. (2016, March 17). U.S. accuses Islamic State of Genocide. Politico. Retrieved from http:// www.politico.com/story/2016/03/isis-genocide-john -kerry-220916

Trump, D. (2017, February 6). President trump's speech claiming the press doesn't report terror attacks. Time. Retrieved from http://time.com/4661658/donaldtrump-terror-attacks-speech-macdill-air-force-base

Uehling, G. (2015). Genocide's aftermath: Neostalinism in contemporary Crimea. Genocide Studies and Prevention: An International Journal, 9(1), 3-17.

Waller, J. (2016). Confronting evil: Engaging our responsibility to prevent Genocide. Oxford: Oxford University Press.

Weiss, T. G. (2007). Halting genocide: Rhetoric versus reality. Genocide Studies and Prevention: An International Journal, 2(1), 7-30.

Weiss, T. G. (2012). Humanitarian intervention: Ideas in action (2nd ed.). Cambridge: Polity Press.

Weiss-Wendt, A. (in press). A rhetorical crime: Genocide in the geopolitical discourse of the Cold War. New Brunswick, NJ: Rutgers University Press.

Wereszczyński, A. (1928). Państwo Antyczne I Jego Renesansy: Przyczynki do Reformy Ustroju Polski [The ancient State and its renaissance: Reasons to reform the 
Ustroje Polski]. Lwów: Wydaw Zakł.

Wille, B. (2016a, November 3). Iraq blames the Islamic State's victims. Human Rights Watch. Retrieved from https://www.hrw.org/news/2016/11/03/iraqblames-islamic-states-victims

Wille, B. (2016b, November 16). For Iraq's Sunni Arabs, you can't go home again. Human Rights Watch. Retrieved from https://www.hrw.org/news/2016/ 11/16/iraqs-sunni-arabs-you-cant-go-home-again

Wittfogel, K. (1931). Wirtschaft und Gesellschaft Chinas, Versuch der wissenschaftlichen Analyse einer großen asiatischen Agrargesellschaft [Economy and society of China: A scientific analysis of a large Asian agricul- tural society]. Leipzig: Hirschfeld.

Wittfogel, K. (1938). Die Theorie der Orientalischen Gesellschaft [The theory of Oriental society]. Zeitschrift Für Sozialforschung, 7(1/2).

Wittfogel, K. (1957). Oriental despotism: A comparative study of total power. New Haven, CT: Yale University Press.

Wood, A. (2008, May 26). Ukrainian President warmly welcomed by Parliament. Toronto Star. Retrieved from https://www.thestar.com/news/world/2008/ 05/26/ukrainian_president_warmly_welcomed_by_ parliament.html

\section{About the Author}

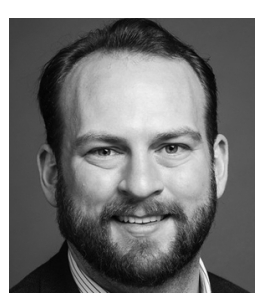

Douglas Irvin-Erickson is a Fellow of Peacemaking Practice, Director of the Genocide Prevention Program, and Assistant Professor at the George Mason University School for Conflict Analysis and Resolution, Arlington, Virginia, USA. 